\title{
ВОЗМОЖНОСТЬ ОБРАЗОВАНИЯ ВЫРОЖДЕННОЙ ТОЧКИ МИНИМУМА НА ФАЗОВОЙ ДИАГРАММЕ СИСТЕМЫ Cd-Mg
}

\author{
() 2017 Ю. М. Бондарев, Е. Г. Гончаров, А. И. Клюсова, А. В. Уланова \\ Воронежский государственный университет, Университетская пл., 1, 394018 Воронеж, Россия \\ e-mail: bondare@chem.vsu.ru \\ Поступила в редакцию 29.06.2017 г.
}

\begin{abstract}
Аннотация. Измерением концентрационных зависимостей параметров образцов системы кадмий-магний определена область твердых растворов с немонотонным изменением физикохимических и электрофизических свойств, а также предложен возможный механизм образования точки минимума на фазовой диаграмме данной системы со стороны кадмия.
\end{abstract}

Ключевые слова: твердые растворы, минимальная точка, вырождение.

\section{ВВЕДЕНИЕ}

Фазовая диаграмма системы Cd-Mg исследовалась неоднократно [1-4] и представляет собой диаграмму, отражающую неограниченную растворимость компонентов как в жидком, так и в твердом состоянии (рис. 1). Однако характер концентрационных зависимостей линий ликвидус и солидус вблизи чистого кадмия позволяет предположить возможность существования в данном концентрационном интервале минимальной точки, где соприкасаются линии ликвидус и солидус. Такое предположение обосновывается практически полным вырождением обеих кривых фазовых равновесий в прямую линию, а прецизионное измерение температур плавления (кристаллизации) в этой области позволит определить относительно небольшой подъем кривых ликвидуса и солидуса после образования минимальной точки, которую по аналогии с вырожденной эвтектикой можно охарактеризовать вырождением состава точки минимума фазовой диаграммы.

Считается [5, 6], что существование на фазовой диаграмме с неограниченной твердофазной растворимостью единственного состава твердого раствора, плавящегося при постоянной температуpe, возможно при упорядочении кристаллической структуры в данной концентрационной области. В этом случае при постоянной температуре могут одновременно разорваться большинство химических связей с образованием гомогенного расплава. Плавление всех других сплавов твердых растворов системы, составы которых лежат слева и справа от точки минимума, протекает в интервале температур. В связи с этим представляется необходимым исследовать физико-химические и электрофизические свойства в интервале составов со стороны кадмия, лежащих вблизи предполагаемой точки минимума фазовой диаграммы. В этом интервале возможно протекание процессов, связанных с переходом от нонвариантного к моновариантному плавлению твердого раствора.

С учетом изложенного, цель настоящей работы состояла в выяснении физико-химической природы структурных преобразований вблизи предполагаемой точки минимума, а также определение состава этой точки. Для достижения поставленной цели необходимо было решить задачу по синтезу серии образцов разбавленных твердых растворов $\mathrm{Cd}_{1-x} \mathrm{Mg}_{x}$ вблизи кадмия и исследовать их свойства.

\section{ОБЪЕКТ ИССЛЕДОВАНИЯ И МЕТОДИКА ЭКСПЕРИМЕНТА}

Объектом исследования являлись поликристаллические образцы разбавленных твердых растворов $\mathrm{Cd}_{1-x} \mathrm{Mg}_{x}$. Для изучения возможности образования точки минимума на фазовой диаграмме системы Cd-Mg был выбран концентрационный интервал

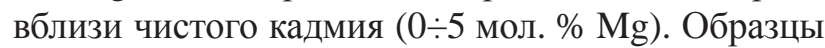
системы Cd-Mg были приготовлены прямым сплавлением компонентов, в качестве которых использованы кадмий марки Кд0А (ГОСТ 1467-93) и магний Мг98 (ГОСТ 804-93), дополнительно очищенные от оксидов двукратной сублимацией в вакууме. 


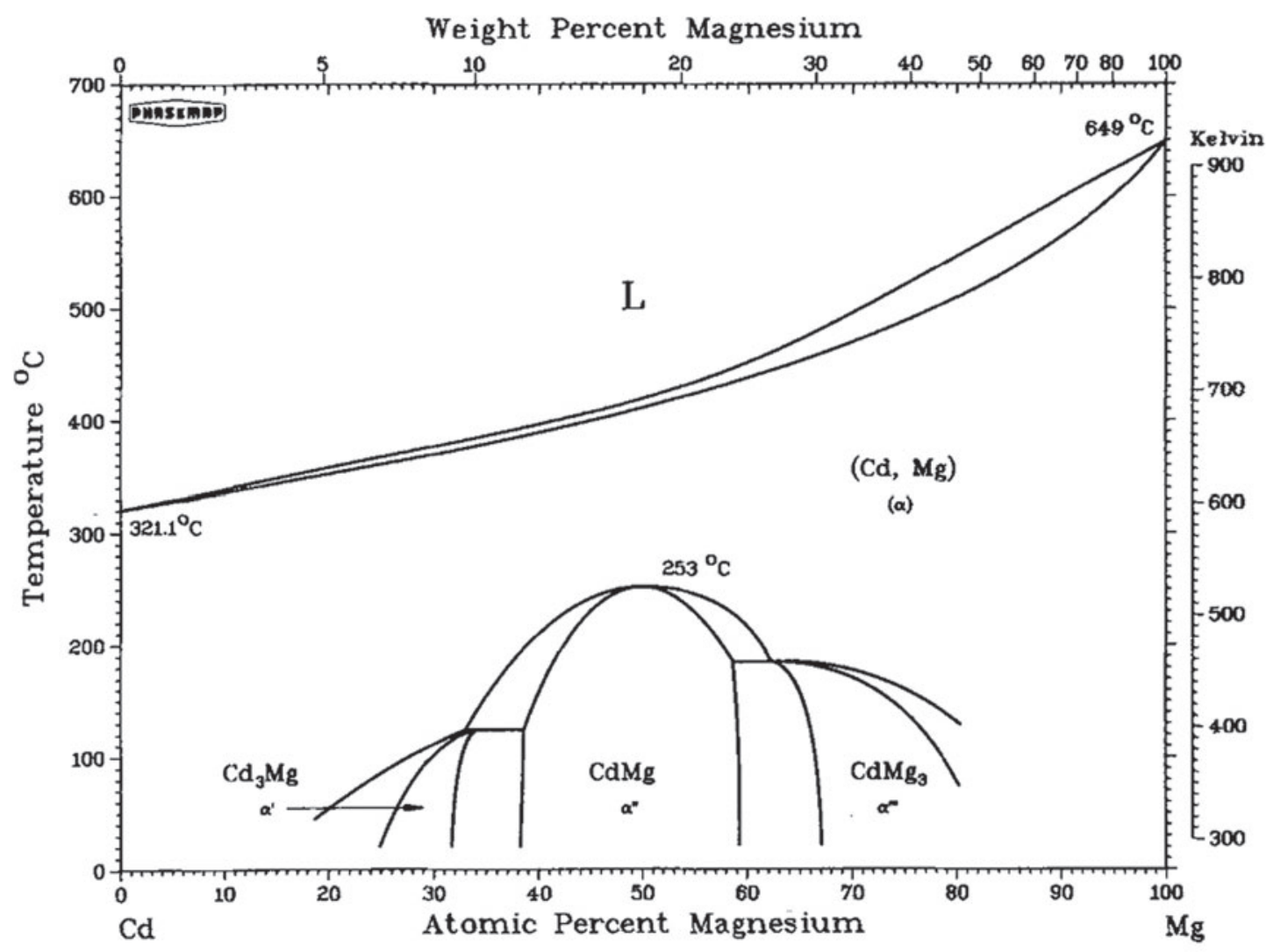

Рис. 1. Фазовая диаграмма системы Cd-Mg [4]

[Fig. 1. Phase diagram of the Cd-Mg system [4]]

Синтез компонентов осуществлялся в кварцевых ампулах, вакуумированных до остаточного давления $5 \cdot 10^{-4}$ гПа при температуре на $10-20 \mathrm{~K}$ выше точки кривой ликвидуса данного сплава. С целью повышения температурной стойкости ампул и снижения химического взаимодействия между кварцевой ампулой и компонентами шихты внутреннюю поверхность ампулы графитизировали. Взвешивание компонентов выполняли на аналитических весах ВЛР-20 с погрешностью $\pm 5 \cdot 10^{-4}$ г. Для гомогенизации расплав подвергался изотермической выдержке в течение трех часов, после чего проводилось закаливание образцов в холодную воду для сведения к минимуму ликвационных процессов.

На синтезированных образцах системы кадмий-магний провели ряд измерений их свойств. При измерении удельного сопротивления сплавов (рис. 2) использовался четырёхзондовый метод Вальдеса. Рентгенографические исследования образцов проводили методом порошка на дифрактометре ДРОН 4-07 с фильтрованным $\mathrm{CuK \alpha} \alpha$-излучением, имеющим длину волны $\lambda=0.154059$ нм. Съемку проводили в дискретном режиме с шагом $0.1^{\circ}$, время экспозиции в каждой точке составляло 1 сек. Обработка экспериментальных результатов осуществлялась по специальным программам на PC Pentium III, работающем в комплексе с дифрактометром. Погрешность определения межплоскостных расстояний $d_{\mathrm{hkl}}$ не превышала $5 \cdot 10^{-5} \mathrm{HM}$.

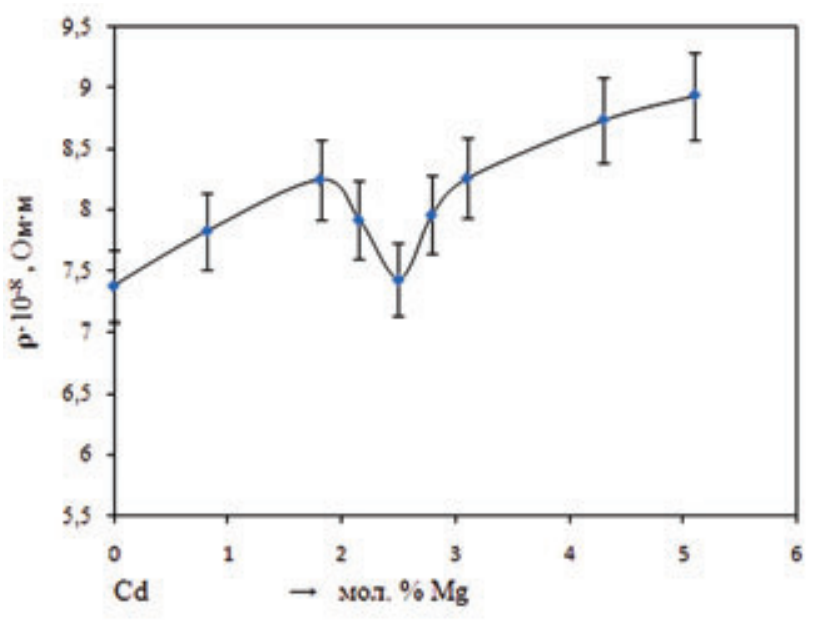

Pис. 2. Концентрационная зависимость удельного сопротивления образцов системы $\mathrm{Cd}-\mathrm{Mg}$

[Fig. 2. Concentration dependence of the resistivity of samples of the Cd-Mg system] 


\section{РЕЗУЛЬТАТЫ И ИХ ОБСУЖДЕНИЕ}

На рис. 2 приведена концентрационная зависимость удельного сопротивления образцов, состав которых лежит в области предполагаемой точки минимума фазовой диаграммы. Из графика видно, что вблизи состава 2.5 мол. \% Mg наблюдается заметный спад удельного сопротивления, что можно объяснить уменьшением рассеяния носителей тока в результате упорядочения структуры твердого раствора данного состава.

Приведенные на рис. 3 концентрационные зависимости параметров $a$ и с образцов системы $\mathrm{Cd}-\mathrm{Mg}$ можно интерпретировать как структурные преобразования твердых растворов, происходящие вблизи точки минимума на фазовой диаграмме. Из литературных данных [7] известно, что для кадмия, кристаллизующегося в гексагональной решетке, характерно отношение параметров $c / a=1.8859$, сильно отличающееся от идеального для гексагональной шаровой упаковки $(c / a=1.663)$. В то же время, для второго компонента системы - магния - это отношение, равное 1.6235, гораздо ближе к выше приведенному значению для идеальной упаковки. Этот факт

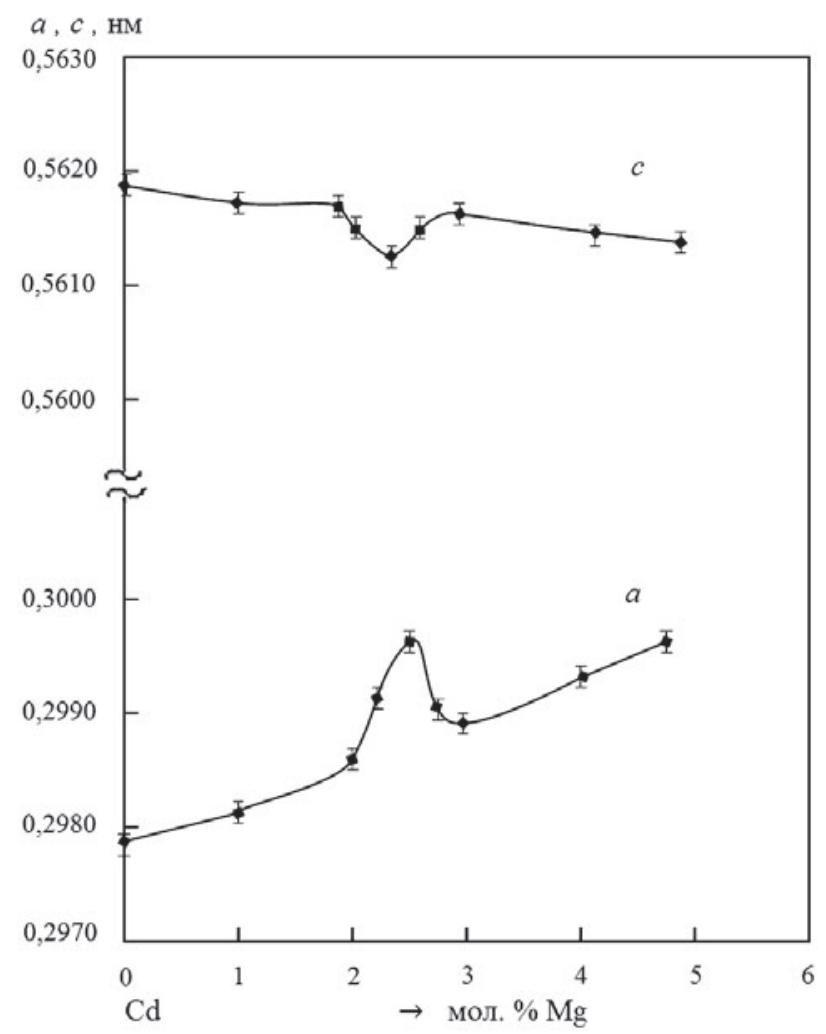

Рис. 3. Концентрационные зависимости параметров $a$ и $c$ элементарной ячейки образцов системы $\mathrm{Cd}-\mathrm{Mg}$

[Fig. 3. Concentration dependencies of the parameters $a$ and $c$ Unit cell of the samples of the Cd-Mg system] дает основание предположить, что в области очень разбавленных твердых растворов на основе кадмия появление в кристаллической решетке кадмия атомов магния приводит к усреднению одноименных и разноименных связей $\mathrm{Cd}-\mathrm{Cd}$ и $\mathrm{Mg}-\mathrm{Cd}$.

В дополнение к этому факту следует учитывать, что в данной области концентраций возможно упорядочение в сплавах в результате взаимного перемещения ближайших соседних атомов, так что атомы кадмия занимают наиболее удаленные друг от друга места [8]. Из графика (рис. 3) видно, что изменение состава твердого раствора от чистого кадмия в сторону увеличения содержания магния приводит к образованию максимума на концентрационной зависимости постоянной решетки $a$, и, соответственно, минимума на кривой $c=f(x)$. Появление разнонаправленных экстремумов на зависимостях $а$ и $с$ в одном концентрационном интервале приводит к усреднению одноименных и разноименных связей в кристаллической решетке твердых растворов замещения (ГПУ) системы Cd-Mg. При этом состав минимальной точки соответствует максимальному усреднению связей.

Таким образом, полученные экспериментальные данные позволяют предположить существование на фазовой диаграмме Cd-Mg вблизи чистого кадмия вырожденной точки минимума, как это показано на рис. 4.

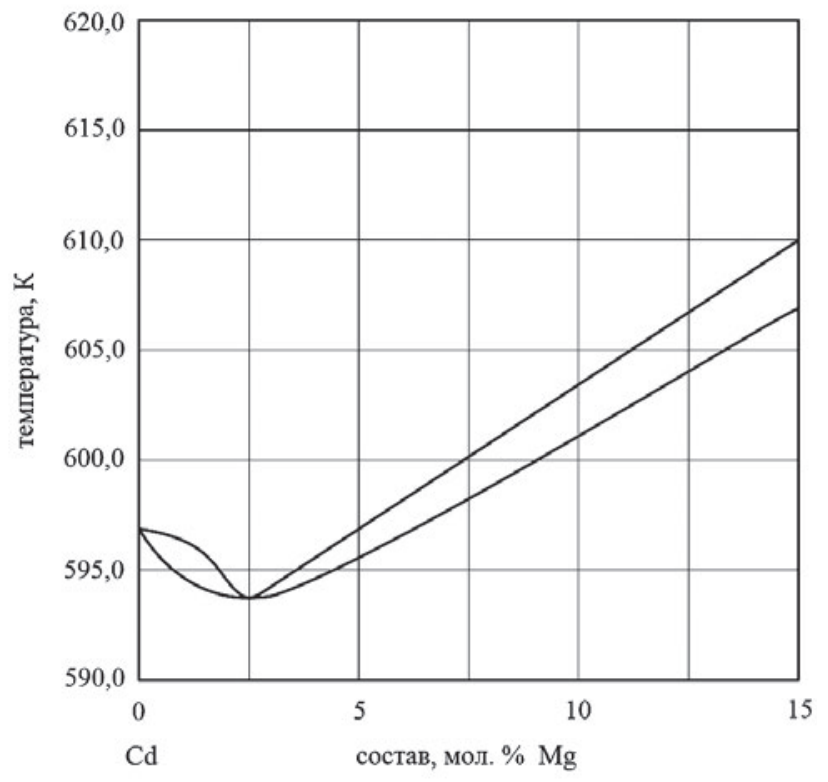

Рис. 4. Формирование на фазовой диаграмме $\mathrm{Cd}-\mathrm{Mg}$ вблизи чистого кадмия «вырожденной» точки минимума

[Fig. 4. Formation in the phase diagram of Cd-Mg near the pure cadmium of the "degenerate" minimum point] 


\section{ЗАКЛЮЧЕНИЕ}

Приведенные в работе результаты позволяют предположить, что склонность твердых растворов к структурным упорядочениям вблизи чистых компонентов может проявляться также в образовании на фазовой диаграмме точки минимума с инвариантным плавлением твердого раствора в этой точке.

Окончательное подтверждение возможности формирования вырожденной точки минимум можно получить проведением прецизионного дифференциально-термического анализа, который даст возможность оценить температурный подъем линий ликвидус и солидус после состава 2.5 мол. \% Mg.

\section{СПИСОК ЛИТЕРАТУРЫ}

1. Хансен М., Андерко К. Структуры двойныхх сплавов. М.: Металлургия, 1962, т. 1, с. 473-475.

2. Эллиот Р. П. Структуры двойнылх сплавов. М.: Металлургия, 1970, т. 1, с. 273.

3. Вол А. Е., Каган И. К. Строение и свойства двойных металлических систем. М.: Наука, 1979, с. 28-75.

4. Moser Z., Gasior W., Wypartowicz J., Zabdyr L. // Bulletin of Alloy Phase Diagrams, 1984, vol. 5, № 1, pp. 23-30.

5. Гончаров Е. Г., Семенова Г. В., Алейникова К. Б., Вавресюк И. В. В кн. Физико-химия полупроводникового материаловедения. Воронеж, ВГУ, 1979, с. 67-73.

6. Гончаров Е. Г., Бондарев Ю. М., Ховив А. М., Семенова Г. В. // Журнал неорганической химии, 2013, т. 58, № 10, с. 1381-1384.

7. Краткая химическая энииклопедия. М.: Советская энциклопедия, 1963, т. 2, с. 343, 1010.

8. Хансен М., Андерко К. Структуры двойных сплавов. М.: Металлургия, 1962, т. 1, с. 454.

\title{
POSSIBILITY OF FORMATION OF DEGENERATE POINT OF MINIMUM ON PHASE DIAGRAM OF SYSTEM Cd-Mg
}

\author{
(C) 2017 Yu. M. Bondarev, E. G. Goncharov, A. I. Klyusova, A. V. Ulanova \\ Voronezh State University, 1 Universitetskaya sq., 394018 Voronezh, Russia \\ e-mail:bondare@chem.vsu.ru
}

Received 29.06.2017

\begin{abstract}
The purpose of the work was to clarify the physical and chemical nature of structural transformations near the alleged valley, and also definition of structure of this point. For the achievement of the goal it was necessary to solve the problem of the synthesis of a series of the diluted solid solutions $\mathrm{Cd}_{1-\mathrm{x}} \mathrm{Mg}_{\mathrm{x}}$ near cadmium and to investigate their properties.

For the research into the of a possibility of the formation of the valley on the phase diagram of the $\mathrm{Cd}-\mathrm{Mg}$ system, the a concentration interval near clear cadmium was chosen $(0 \div 5 \mathrm{~mol}$. \% Mg). Samples of the Cd-Mg system were prepared by direct alloying of components, which used Cd markings Kd0A and magnesium Mg98, additionally purified from oxides by double sublimation in vacuum. For homogenization, the melt was isothermally aged for three hours, after which the samples were quenched in cold water to minimize the segregation processes.

Measuring the concentration dependence of the parameters cadmium-magnesium system samples determined range of solid solutions with non-monotonic change in the physicochemical and electrical properties.

The obtained experimental datas allows us to assume the existence on the phase diagram of the $\mathrm{Cd}-\mathrm{Mg}$ near clear cadmium of the degenerate valley as it is shown in fig. 4 .

The results given in the work allow us to assume that the tendency of solid solutions to structural streamlinings near clear components can be shown also in education on the phase diagram of the valley with invariant melting of a solid solution in this point.

Final confirmation of a possibility of formation of a degenerate point at least can be received carrying out a high-precision differential thermal analysis which will give the chance to estimate temperature raising of lines a liquidus and a solidus after structure $2.5 \mathrm{~mol}$. $\mathrm{Mg} \%$.
\end{abstract}

Keywords: solid solutions, the minimum point, degeneration. 


\section{REFERENCES}

1. Hansen M., Anderko K. Structures of Binary Alloys. Moscow, Metallurgy Publ., 1962, vol. 1, pp. 473-475. (in Russian)

2. Jelliot R. P. Structures of Binary Alloys. Moscow, Metallurgy Publ., 1970, vol. 1, p. 273. (in Russian)

3. Vol A. E., Kagan I. K. Structure and Properties of Binary Metal Systems. Moscow, Nauka Publ., 1979, pp. 2875. (in Russian)

4. Moser Z., Gasior W., Wypartowicz J., Zabdyr L. Bulletin of Alloy Phase Diagrams, 1984, vol. 5, no. 1, pp. 23-30.
5. Goncharov E. G., Semenova G. V., Aleinikova K. B., Vavresuk I. V. In the book Physics and Chemistry of Semiconductor Material Science. Voronezh, VSU Publ., 1979, pp. 67-73. (in Russian)

6. Bondarev Yu. M., Goncharov E. G., Khoviv A. M., Semenova G. V. Russian Journal of Inorganic Chemistry, 2013, vol. 58, no. 10, pp. 1381-1384.

7. Brief Chemical Encyclopaedia. Moscow, Soviet Encyclopaedia Publ., 1963, vol. 2, pp. 343, 1010. (in Russian)

8. Hansen M., Anderko K. Structures of Binary Alloys. Moscow, Metallurgy Publ., 1962, vol. 1, pp. 454. (in Russian)
Бондарев Юрий Максимович - к. х. н., доцент, Воронежский государственный университет; тел.: +7(473) 2208973; e-mail: bondarev@chem.vsu.ru

Гончаров Евгений Григорьевич - д. х. н., професcop, Воронежский государственный университет; тел.: $+7(473) 2208973$

Клюсова Анастасия Игоревна - магистрант химического факультета, Воронежский государственный университет; тел.: +7(473) 2208610

Уланова Алена Васильевна - магистрант химического факультета, Воронежский государственный университет; тел.: +7(473) 2208610
Bondarev Yury M. - Cand. Sci. (Chem.), Associate Professor, Voronezh State University; ph.: +7(473) 2208973; e-mail: bondarev@chem.vsu.ru

Goncharov Eugeny G. - Dr. Sci. (Chem.), Professor, Voronezh State University; ph.: (473) 2208973

Kljusova Anastasija I. - Master of Chemistry Faculty, Voronezh State University; ph.: +7(473) 2208610

Ulanova Alena V. - Master of Chemistry Faculty, Voronezh State University; ph.: +7(473) 2208610 